\title{
The Human Immunoglobulin $\mathrm{V}_{\mathrm{H}}$ Gene Repertoire is Genetically Controlled and Unaltered by Chronic Autoimmune Stimulation
}

\author{
Hitoshi Kohsaka, ${ }^{\star}$ Dennis A. Carson, ${ }^{\S}$ Laura Z. Rassenti, ${ }^{\S}$ William E.R. Ollier, ${ }^{\|}$Pojen P. Chen, ${ }^{\S}$ Thomas J. Kipps, ${ }^{\S}$ \\ and Nobuyuki Miyasaka ${ }^{\ddagger}$ \\ $*$ Division of Immunological Diseases, Medical Research Institute, and ${ }^{\ddagger}$ First Department of Internal Medicine, Tokyo Medical and Dental \\ University, Tokyo, 113, Japan; ${ }^{\S}$ Department of Medicine, Sam and Rose Stein Institute for Research on Aging, University of California, \\ San Diego, La Jolla, California 92093; and $\|_{A R C}$ Epidemiology Research Unit, University of Manchester, Manchester, M13 9PT, \\ United Kingdom
}

\begin{abstract}
The factors controlling immunoglobulin (Ig) gene repertoire formation are poorly understood. Studies on monozygotic twins have helped discern the contributions of genetic versus environmental factors on expressed traits. In the present experiments, we applied a novel anchored PCR-ELISA system to compare the heavy chain $\mathrm{V}$ gene $\left(\mathrm{V}_{\mathrm{H}}\right)$ subgroup repertoires of $\mu$ and $\gamma$ expressing B lymphocytes from ten pairs of adult monozygotic twins, including eight pairs who are concordant or discordant for rheumatoid arthritis. The results disclosed that the relative expression of each $\operatorname{Ig} V_{H}$ gene subgroup is not precisely proportional to its relative genomic size. The monozygotic twins had more similar IgM $\mathrm{V}_{\mathrm{H}}$ gene repertoires than did unrelated subjects. Moreover, monozygotic twins who are discordant for RA also use highly similar IgM $V_{H}$ gene-subgroup repertoires. Finally, the $V_{H}$ gene repertoire remained stable over time. Collectively, these data reveal that genetic factors predominantly control $\mathrm{V}_{\mathrm{H}}$ gene repertoire formation. (J. Clin. Invest. 1996. 98:2794-2800.) Key words: monozygotic twins - B cell • rheumatoid arthritis • PCR • ELISA
\end{abstract}

\section{Introduction}

B cells produce immunoglobulins (Ig) as effector molecules and as antigen receptors. The mature Ig molecule is the product of multiple non-contiguous gene segments. The variable regions of $\mathrm{Ig} \mathrm{H}$ chains are assembled from variable $\left(\mathrm{V}_{\mathrm{H}}\right)$, diversity $\left(\mathrm{D}_{\mathrm{H}}\right)$ and joining $\left(\mathrm{J}_{\mathrm{H}}\right)$ genes. The human $\mathrm{V}_{\mathrm{H}}$ complex is composed of approximately 100 gene segments per haploid genome, including at least 51 functional genes, as judged by successful rearrangement in cloned cDNA. The remainder are either pseudogenes or potentially functional genes never found productively rearranged. On the basis of nucleic acid sequence homology, the $\mathrm{V}_{\mathrm{H}}$ genes have been grouped into 6-7 families. Among the seven families, the $\mathrm{V}_{\mathrm{H}} 3$ family is the largest, and

Address correspondence to Hitoshi Kohsaka, M.D., Division of Immunological Diseases, Medical Research Institute, Tokyo Medical and Dental University, 1-5-45 Yushima, Bunkyo-ku, Tokyo, 113, Japan. Phone: 81-3-5803-5819; FAX: 81-3-5684-0717 or 81-3-5684-0057; E-mail: kohsaka.imm@tmd.ac.jp

Received for publication 28 May 1996 and accepted in revised form 15 October 1996.

J. Clin. Invest.

(C) The American Society for Clinical Investigation, Inc. 0021-9738/96/12/2794/07 \$2.00

Volume 98, Number 12, December 1996, 2794-2800 consists of 22 functional genes. The $\mathrm{V}_{\mathrm{H}} 1$ and $\mathrm{V}_{\mathrm{H}} 4$ families each contain approximately a dozen functional genes, and $\mathrm{V}_{\mathrm{H}} 2$, $\mathrm{V}_{\mathrm{H}} 5, \mathrm{~V}_{\mathrm{H}} 6$, and $\mathrm{V}_{\mathrm{H}} 7$ families contain $3,2,1$, and 1 functional genes, respectively (1).

Although human fetal B lymphocytes rearrange and express a highly restricted set of $\mathrm{V}_{\mathrm{H}}$ genes (2-6), the frequency of Ig $\mathrm{V}_{\mathrm{H}}$ gene rearrangement in cord blood lymphocytes is roughly proportional to $\mathrm{V}_{\mathrm{H}}$ family size (7). In adults, some genes such as $V_{H} 18 / 2$, and $V_{H} 4.21$ are expressed in high frequency (8-10). Deletions or duplications of individual $V_{H}$ genes may partially explain their relative expression through a gene dosage effect (11). However, inherited differences in regulatory or coding sequences and/or environmental stimuli could also influence $\mathrm{V}_{\mathrm{H}}$ gene expression.

Previous studies on $\mathrm{T}$ cell receptor variable region gene (TCRV) alleles revealed that apparently minor sequence polymorphisms can affect gene expression in the periphery (1214). By analyzing monozygotic adult twins, we disclosed that the TCRV gene repertoires of $\alpha \beta \mathrm{T}$ lymphocytes are controlled mainly by genetic factors. In contrast, the repertoire of $\gamma \delta$ lymphocytes depends principally on environmental stimuli (15). HLA is the predominant genetic factor in TCRBV repertoire formation, whereas polymorphisms of TCRV genes probably play a lesser role (16-18).

The goals of the present investigations were to ascertain the genetic regulation and stability of human $\mathrm{Ig} \mathrm{V}_{\mathrm{H}}$ gene expression, and to determine if a chronic immunologic disease, rheumatoid arthritis (RA), could unbalance the repertoire. Both $\mu$ and $\gamma$ transcripts were analyzed from 10 pairs of monozygotic twins, including two normal pairs, four pairs discordant, and four pairs concordant for RA. The problem of Ig $\mathrm{V}_{\mathrm{H}}$ gene diversity was avoided by application of a quantitative anchored PCR-ELISA technology $(19,20)$. The results showed that the expression of $\mathrm{V}_{\mathrm{H}}$ genes in adults was not proportional to $\mathrm{V}_{\mathrm{H}}$ gene family size. The $\mathrm{V}_{\mathrm{H}} 3$ and $\mathrm{V}_{\mathrm{H}} 4$ gene families were dominant in $\mu$ and $\gamma$ transcripts, while the large $\mathrm{V}_{\mathrm{H}} 1$ gene family was underrepresented. Regardless of the presence or absence of RA, the peripheral B cells from monozygotic twins had homologous and distinctive patterns of $\mathrm{V}_{\mathrm{H}}$ family gene expression. Also, the $\mathrm{V}_{\mathrm{H}}$ gene-subgroup expression pattern for each individual remained stable, over 6 month period of observation. Thus, genetic factors primarily control $\mathrm{V}_{\mathrm{H}}$ family gene repertoire formation in humans. The inherited pattern of $V_{H}$ expression is not grossly altered by time, or chronic systemic autoimmune disease.

\section{Methods}

Clinical samples. Monozygotic twins with RA were identified in the course of epidemiological investigations on RA in the United King- 
Table I. RA Monozygotic Twins Studied

\begin{tabular}{|c|c|c|c|c|}
\hline Twin & Age & Sex & $\begin{array}{l}\text { Duration } \\
\text { of disease }\end{array}$ & HLA DR \\
\hline \multicolumn{5}{|c|}{ Discordant twins } \\
\hline A1 & 65 & $\mathrm{~F}$ & $25 \mathrm{yr}$ & $4 / 10$ \\
\hline A2 & 65 & $\mathrm{~F}$ & No disease & $4 / 10$ \\
\hline B1 & 44 & $\mathrm{~F}$ & $9 \mathrm{yr}$ & $3 / 7$ \\
\hline B2 & 44 & $\mathrm{~F}$ & No disease & $3 / 7$ \\
\hline $\mathrm{C} 1$ & 47 & M & No disease & 2 \\
\hline $\mathrm{C} 2$ & 47 & $\mathrm{M}$ & $1 \mathrm{yr}$ & 2 \\
\hline D1 & 64 & $\mathrm{~F}$ & No disease & $2 / 11$ \\
\hline $\mathrm{D} 2$ & 64 & $\mathrm{~F}$ & $14 \mathrm{yr}$ & $2 / 11$ \\
\hline \multicolumn{5}{|c|}{ Concordant twins } \\
\hline E1 & 55 & $\mathrm{~F}$ & $19 \mathrm{yr}$ & $1 / 6$ \\
\hline $\mathrm{E} 2$ & 55 & $\mathrm{~F}$ & $11 \mathrm{yr}$ & $1 / 6$ \\
\hline $\mathrm{F} 1$ & 39 & $\mathrm{~F}$ & $19 \mathrm{yr}$ & 4 \\
\hline $\mathrm{F} 2$ & 39 & $\mathrm{~F}$ & $19 \mathrm{yr}$ & 4 \\
\hline G1 & 57 & $\mathrm{~F}$ & $27 \mathrm{yr}$ & $1 / 6$ \\
\hline $\mathrm{G} 2$ & 57 & $\mathrm{~F}$ & $22 \mathrm{yr}$ & $1 / 6$ \\
\hline $\mathrm{H} 1$ & 42 & $\mathrm{~F}$ & $19 \mathrm{yr}$ & $1 / 4$ \\
\hline $\mathrm{H} 2$ & 42 & $\mathrm{~F}$ & $24 \mathrm{yr}$ & $1 / 4$ \\
\hline
\end{tabular}

All affected twins were seropositive. Homozygosity for HLA-DRB shared epitope was a potent risk factor for disease concordance (38).

dom (21). Two normal pairs were identified in Tokyo and San Diego. They were all Caucasians except for one pair of Japanese twins. Monozygosity of the studied twins was confirmed by genotype analysis using anonymous probes. RA was diagnosed according to the American College of Rheumatology criteria (22). The affected twins were seropositive for rheumatoid factors. The clinical profiles of the RA monozygotic twins are shown in Table I. The patients had active disease when their blood samples were collected. Peripheral blood mononuclear cells (PBMC) were isolated with density gradient sedimentation.

Oligonucleotides. PCR primers, $\mathrm{C} \mu 1$ (5'-GGA ATT TCT CAC AGG AGA CGA) and BTNC $\mu 2$ (5'-biotin- AAA AGG GTT GGG GCG GAT GCA CT) were specific for the human $\operatorname{IgC} \mu$ gene. BTNC $\mu 2$ was reacted with biotinylated phosphoramadite (Clontech, Palo Alto, CA). PCR Primers, C $\gamma 1$ (5'-CCT GAG TTC CAC GAC ACC GT) and BTNC $\gamma 2$ (5'-biotin-GTA GTC CTT GAC CAG GCA) were specific for the human IgC $\gamma$ gene, and BTNC $\gamma 2$ was biotinylated likewise. The $\mathrm{C} \mu 1$ and $\mathrm{C} \gamma 1$ were used for primary APCR; BTNC $\mu 2$ and BTNC $\gamma 2$ were used for nested PCR amplification of $\mathrm{V}_{\mathrm{H}}$ domain cDNA of IgM and IgG heavy chains, respectively. Anchor primers, ANC and AN were the same ones used previously for APCR of TCR cDNA (23). The Ig $\mathrm{V}_{\mathrm{H}}$ genes were classified into $\mathrm{V}_{\mathrm{H}} 1-6$ families. A small, recently identified $V_{H} 7$ family was included in $V_{H} 1$ family, which is related most closely. Based on all $\mathrm{V}_{\mathrm{H}}$ gene sequences published in the literature and data bases (24), 6 sense-strand oligonucleotides were designed to specify the leader sequences of the $\mathrm{V}_{\mathrm{H}} 1$ $\mathrm{V}_{\mathrm{H}} 6$ gene families $\left(\mathrm{V}_{\mathrm{H}} 1\right.$ probe: $5^{\prime}$-ATG GAC TGG ACC TGG AGG, $\mathrm{V}_{\mathrm{H}} 2$ probe: 5'-ATA CTT TGT TCC ACG CTC CT, $\mathrm{V}_{\mathrm{H}} 3$ probe: 5'-GAG TTT GGG CTG AGC TGG, $\mathrm{V}_{\mathrm{H}} 4$ probe: $5^{\prime}-\mathrm{CTG}$ GTG GCA GCT CCC AGA, $V_{\mathrm{H}} 5$ probe: $5^{\prime}$-ATC CTC GCC CTC CTC CTG, $\mathrm{V}_{\mathrm{H}} 6$ probe: 5'-TGT CTC CTT CCT CAT CTT CC). The theoretical dissociation temperatures of all oligonucleotides to their target Ig leader sequences were $58^{\circ} \mathrm{C}$.

Anchored PCR followed by nested PCR. The DNA templates for PCR amplification of Ig V domain gene from PBMC were prepared as described previously (23). In brief, total RNAs were isolated from the PBMC and converted to single stranded cDNA. After size selec- tion $(0.5-3 \mathrm{~kb})$ and hydrolysis of the remaining RNA, they were poly-G tailed with dGTP and terminal deoxytransferase. Subsequently, free dGTP was removed by two sequential sodium acetate precipitation steps. The dG-tailed first strand cDNA were subjected to primary APCR amplification in $100 \mu \mathrm{l}$ of $10 \mathrm{mM}$ Tris- $\mathrm{HCl}$ (pH 8.3), $50 \mathrm{mM}$ $\mathrm{KCl}, 1.5 \mathrm{mM} \mathrm{MgCl} 2,0.001 \%$ gelatin, $200 \mu \mathrm{M}$ dNTPs, $1 \mathrm{U}$ Perfect Match Polymerase Enhancer (Stratagene, La Jolla, CA), 2.5 U Taq DNA polymerase (Boehringer Mannheim, Indianapolis, IN). The primers consisted of anchor primers (9:1 mixture of AN and ANC primers) and $\mathrm{C} \mu 1$ for IgM heavy chain $\mathrm{V}$ domain cDNA amplification, or $\mathrm{C} \gamma 1$ for IgG heavy chain $\mathrm{V}$ domain cDNA amplification, at a concentration of $0.5 \mu \mathrm{M}$. The amplification consisted of 20 cycles of $95^{\circ} \mathrm{C}$ for $30 \mathrm{~s}, 42^{\circ} \mathrm{C}$ for $30 \mathrm{~s}$, and $72^{\circ} \mathrm{C}$ for $1 \mathrm{~min}$ followed by final extension for $7 \mathrm{~min}$. The products were size selected (500-750 bp) on agarose gels and one third was removed for nested PCR. The reaction mixture was same as that of the primary anchored PCR except for the primers; $0.5 \mu \mathrm{M}$ each of an AN primer and a BTNC $\mu 2$ or BTNC $\gamma 2$ primer were used. The biotinylated primers specified upstream regions of the $\mathrm{C} \mu 1$ or $\mathrm{C} \gamma 1$ priming sequence. Twenty-five cycles of nested PCR were carried out at an annealing temperature of $53^{\circ} \mathrm{C}$, and the products were purified on mini-columns (Wizard PCR preps; Promega, Madison, WI). Nested PCR reactions with the biotinylated primer were performed not only to increase the specificity of the amplification but also to put a biotin molecule at the $5^{\prime}$ end of the antisense strand of the PCR product.

Construction of $V_{H} 1-6$ leader DNA. To standardize hybridization efficiencies of the six probes, a 124-bp DNA fragment which contained tandemly aligned leader specific sequences of each of $\operatorname{six} I g V_{H}$ gene subgroups was generated. A pool of the six $\mathrm{V}_{\mathrm{H}^{-}}$-family specific oligonucleotides and bridging oligonucleotides $\left(\mathrm{V}_{\mathrm{H}} 1 / 2\right.$ : $5^{\prime}-\mathrm{ACA}$ AAG TAT CCT CCA GGT, $\mathrm{V}_{\mathrm{H}} 2 / 3$ : 5' - CAA ACT CAG GAG CCT GGA, V $\mathrm{H}_{\mathrm{H}} 3 / 4: 5^{\prime}$ - GCC ACC AGC CAG CTC AGC C, $\mathrm{V}_{\mathrm{H}} 4 / 5$ : 5' - GCG AGG ATT CTG GGA GCT, V $\mathrm{H}_{\mathrm{H}} 5 / 6: 5^{\prime}$ - AGG AGA CAC AGG AGG AGG. $\mathrm{V}_{\mathrm{H}} 6 / \mathrm{H} ; 5^{\prime}-$ ACC AAG CTT GGA AGA TGA GGA [underlined is a HindIII restriction site]) were mixed, phosphorylated and ligated. The ligated DNA fragment was amplified with an $\mathrm{E} / \mathrm{V}_{\mathrm{H}} 1$ primer (5' - CCA GTC CAT GAA TTC AGA [underlined is a EcoRI restriction site]) and a $\mathrm{V}_{\mathrm{H}} 6 / \mathrm{H}$ primer using Pfu DNA polymerase (Stratagene), and subcloned into pBluescript II SK+ plasmid (Stratagene). The plasmid was linearized with PvuII enzymatic digestion, before amplification of the insert DNA with a T3 primer $\left(5^{\prime}-\right.$ ATT AAC CCT CAC TAA AG) and a BTN T7 primer (5' - biotin-AAT ACG ACT CAC TAT AG). Two primers flanked the pBluescript II SK + multicloning site, and the BTN T7 primer was biotinylated at the $5^{\prime}$ end. The anti-sense strands of the PCR products had complementary sequences to the six $\mathrm{V}_{\mathrm{H}}$ probes, and had biotin molecules at the $5^{\prime}$ ends.

PCR-ELISA. 200- $\mu \mathrm{l}$ aliquots of $8 \mathrm{mg} / \mathrm{ml}$ 1-ethyl-3(3-dimethylaminopropyl) carbodiimide hydrochloride (Pierce, Rockford, IL) and N-hydroxysulfosuccinimide (Pierce) in ME buffer (50 mM MES [2-\{N-morpholino\} ethanesulfonic acid, pH 5.5], $1 \mathrm{mM}$ EDTA) were freshly prepared and incubated in the wells of polystyrene plates with carboxylated surfaces (Covalent EIA plate, Costar, Cambridge, MA) for $15 \mathrm{~min}$. Incubation of the plates with streptavidin and subsequent washing was carried out as described previously (23). Each of the oligonucleotide probes was labeled with a single molecule of digoxigenin using terminal transferase.

DNA hybridization in microtiter wells. Appropriate amounts of each PCR product, resuspended in $100 \mu \mathrm{l}$ of $6 \times$ SSC, $0.1 \%$ Tween20, were distributed among six streptavidin-bound wells. Incubation with $0.1 \mathrm{~N} \mathrm{NaOH}$ stripped away the sense strands, leaving the antisense strands captured on the plates at their biotinylated $5^{\prime}$ ends. Then, $150 \mu \mathrm{l}$ of a $25 \mathrm{pM}$ solution of each digoxigenin labeled sensestrand $\mathrm{V}_{\mathrm{H}}$ specific probe was placed for hybridization at $42^{\circ} \mathrm{C}$.

ELISA of bound probes. After the wells were washed three times, they were incubated with peroxidase-conjugated anti-digoxigenin antibodies (Boehringer Mannheim), and subsequently with tetramethylbenzidine microwell peroxidase substrate (Kirkegaard \& 
Perry Laboratories, Gaithersburg, MD). The reaction was stopped with $1 \mathrm{M} o$-phosphoric acid after 30-60 min and OD values were recorded at $450 \mathrm{~nm}$ with a microplate reader (Molecular Devices, Menlo Park, CA).

The PCR products derived from the standard $\mathrm{V}_{\mathrm{H}} 1-6$ leader DNA generated 6 standard curves for individual $\mathrm{V}_{\mathrm{H}}$ probes. Six sets of 100 $\mu l$ of 1:2 serial dilutions of the amplified $V_{H} 1-6$ leader DNA, ranging from $480 \mathrm{fM}$ to $1 \mathrm{nM}$, were applied onto the streptavidin-bound wells, hybridized with the $\mathrm{V}_{\mathrm{H}}$ leader probes. They were then reacted with peroxidase-conjugated anti-digoxigenin antibodies and its substrate at the same time as the PCR products from the sample cDNA were processed.

The optical densities were transformed to concentrations according to the standard curves using the Deltasoft II software program (Biometallics, Princeton, NJ). Separate standard curves were generated for each experiment to control for potential differences of hybridization efficiencies of the six $\mathrm{V}_{\mathrm{H}}$ probes. The frequency of each $\mathrm{V}_{\mathrm{H}}$ gene use was calculated by dividing the concentration of each $\mathrm{V}_{\mathrm{H}}$ gene product by the total concentration of $\mathrm{V}_{\mathrm{H}}$ genes.

Conventional library screening with DNA dot blot hybridization and nucleotide sequence analysis of the amplified Ig genes. The products of the initial anchored PCR were further amplified with a $\mathrm{C} \gamma 3$ primer (5'-AAT CGT CGA CGT AGT CCT TGA CCA GGC A: underlined is a Sal I recognition site) and an AN primer (which contained a Not I site). The $\mathrm{C} \gamma 3$ and $\mathrm{C} \gamma 1$ primers have the same priming sequence, and the $\mathrm{C} \gamma 3$ has an additional linker sequence at $5^{\prime}$ end. The products were subcloned into pBluescript II SK+ plasmids. Recombinant clones were randomly selected for plasmid DNA dot blotting. An internal $\mathrm{C} \gamma 4$ probe (5'- ATC GGT CTT CCC CCT GGC), a $\mathrm{V}_{\mathrm{H}} 3$ probe, a $\mathrm{V}_{\mathrm{H}} 4$ probe and a mixture of $\mathrm{V}_{\mathrm{H}} 1, \mathrm{~V}_{\mathrm{H}} 2, \mathrm{~V}_{\mathrm{H}} 5$ and $\mathrm{V}_{\mathrm{H}} 6$ probes were labeled, and used for hybridization to calculate frequencies of $\mathrm{V}_{\mathrm{H}} 3$ and $\mathrm{V}_{\mathrm{H}} 4$ family genes (15). The extracted DNA were also used for nucleic acid sequence determination.

Statistical analyses. To compare the $\mathrm{V}_{\mathrm{H}}$ gene repertoires of two subsets of donors, the Euclidean distance was calculated by determining the square root of the sum of the squares of the difference of each $\mathrm{V}_{\mathrm{H}}$ gene frequency. In statistics, the distance represents the linear distance between pairs of land marks in a multiple dimension space. This value was used in the present study, as an indicator of the discordance of two $\mathrm{V}_{\mathrm{H}}$ gene repertoires. P-values were determined with the Mann-Whitney U test, using StatView 4.11 (Abacus Concepts Inc., Berkeley, CA).

\section{Results}

Hybridization. To verify the specificity of the designed oligonucleotide probes for the leader sequences of the $\mathrm{V}_{\mathrm{H}}$ family genes, we tested them for cross-hybridization to unrelated $V_{H}$ genes. Plasmids with rearranged $\mathrm{Ig}$ heavy chain $\mathrm{V}$ domain cDNA clones belonging to the six Ig $\mathrm{V}_{\mathrm{H}}$ families were amplified by conventional PCR with a T3 primer and a $5^{\prime}$ biotinylated BTN T7 primer. The PCR products were distributed equally, captured onto streptavidin-coated ELISA plates, and hybridized with each digoxigenin-labeled leader-specific $V_{H}$ probe. Each probe hybridized specifically to the PCR products of plasmids corresponding to the appropriate $\mathrm{Ig} \mathrm{V}_{\mathrm{H}}$ gene family. With the hybridization conditions described in the Materials and Methods, no cross-hybridization was observed between a probe and a PCR product derived from an irrelevant Ig $\mathrm{V}_{\mathrm{H}}$ family gene (data not shown).

Reproducibility of APCR-ELISA and comparison with conventional methods. IgM heavy chain $\mu$ transcripts from peripheral lymphocytes of a single healthy donor were amplified with two independent amplifications. The $\mathrm{V}_{\mathrm{H}}$ gene frequencies in $\mu$ transcripts from the two experiments are shown in Fig. 1
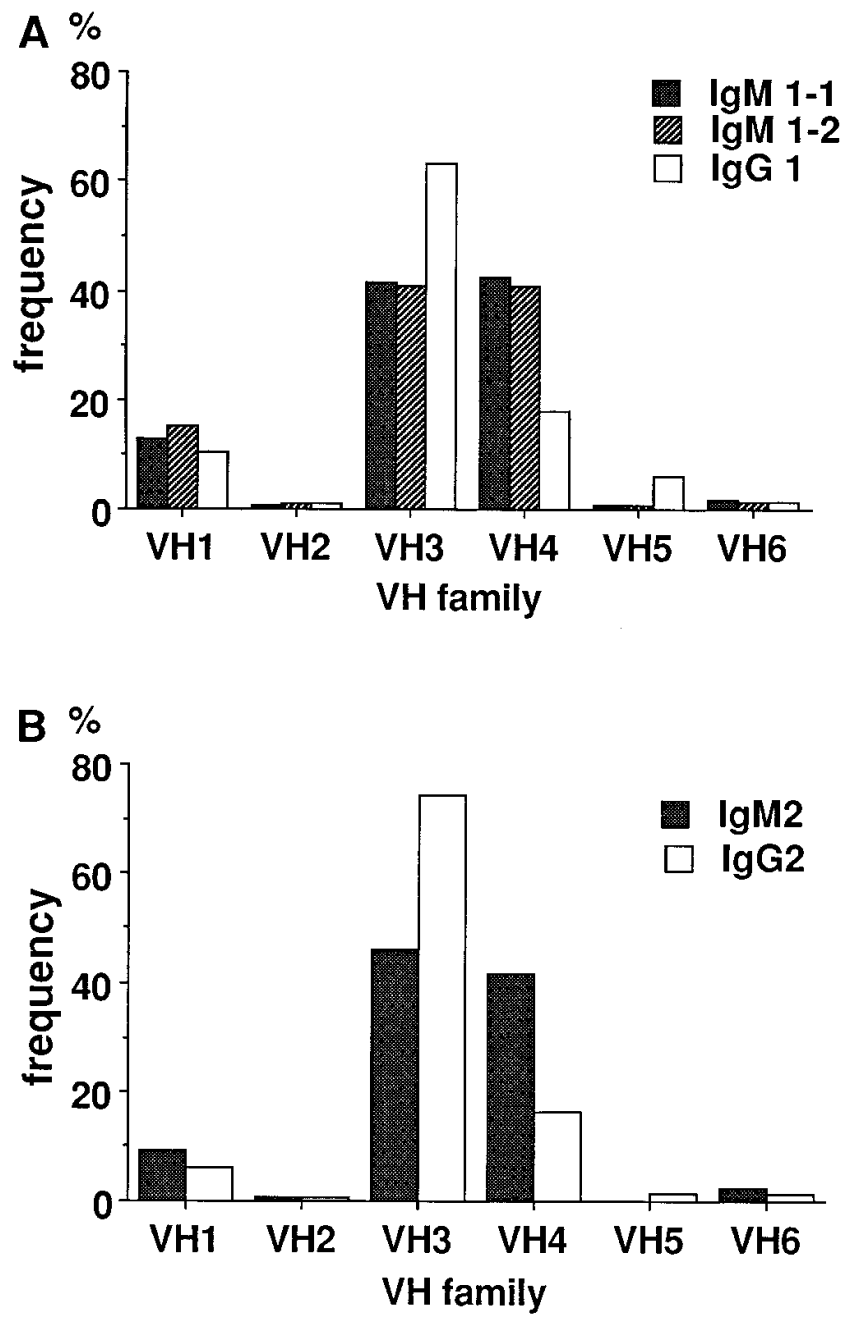

Figure 1. Expressed $\mathrm{V}_{\mathrm{H}} \mu$ and $\gamma$ gene repertoires from a single donor. (A) $\mu$ gene repertoire data were generated with two different amplifications of PBMC cDNA. Each of the results is shown separately (IgM1-1, 2). $\gamma$ gene repertoire is shown for comparison $(\operatorname{IgG1}) .(B) \mu$ and $\gamma$ gene repertoires (IgM2, IgG2) of the same donor six months later.

$A$. The $\mathrm{V}_{\mathrm{H}}$ gene frequencies of $\gamma$ transcripts from the same donor are also shown for comparison. Compared to IgM expressing $B$ cells, the IgG used more $\mathrm{V}_{\mathrm{H}} 3$ family genes and less $\mathrm{V}_{\mathrm{H}} 4$ family genes.

To confirm that the anchored PCR-ELISA data reflect the real frequency of each $V_{H}$ family's gene expression, we amplified $\mathrm{IgG} \mathrm{V}_{\mathrm{H}}$ region $\mathrm{cDNA}$ from the same $\mathrm{cDNA}$, cloned the products into pBluescript II, and randomly selected 56 recombinants for DNA dot blot hybridization with individually labeled $\mathrm{C} \gamma 4, \mathrm{~V}_{\mathrm{H}} 3, \mathrm{~V}_{\mathrm{H}} 4$ probes or with a mixture of $\mathrm{V}_{\mathrm{H}} 1,2,5$, and 6 probes. The frequencies of $\mathrm{V}_{\mathrm{H}} 3$ and $\mathrm{V}_{\mathrm{H}} 4$ family genes were $55 \%$ and $16 \%$, respectively. They corresponded well to the data obtained by the APCR-ELISA method (63\% and $18 \%$ ). Sequence analyses showed that all clones positive with the $\mathrm{C} y 4$ probe had leader sequences homologous to one of the $V_{H}$ leader sequence probes.

To compare the mutation frequencies within the probing sequences of the $\mathrm{V}_{\mathrm{H}} 3$ and $\mathrm{V}_{\mathrm{H}} 4$ genes, we sequenced $24 \mathrm{~V}_{\mathrm{H}} 3$ clones and $13 \mathrm{~V}_{\mathrm{H}} 4$ clones. Among the $24 \mathrm{~V}_{\mathrm{H}} 3$ gene transcripts, 

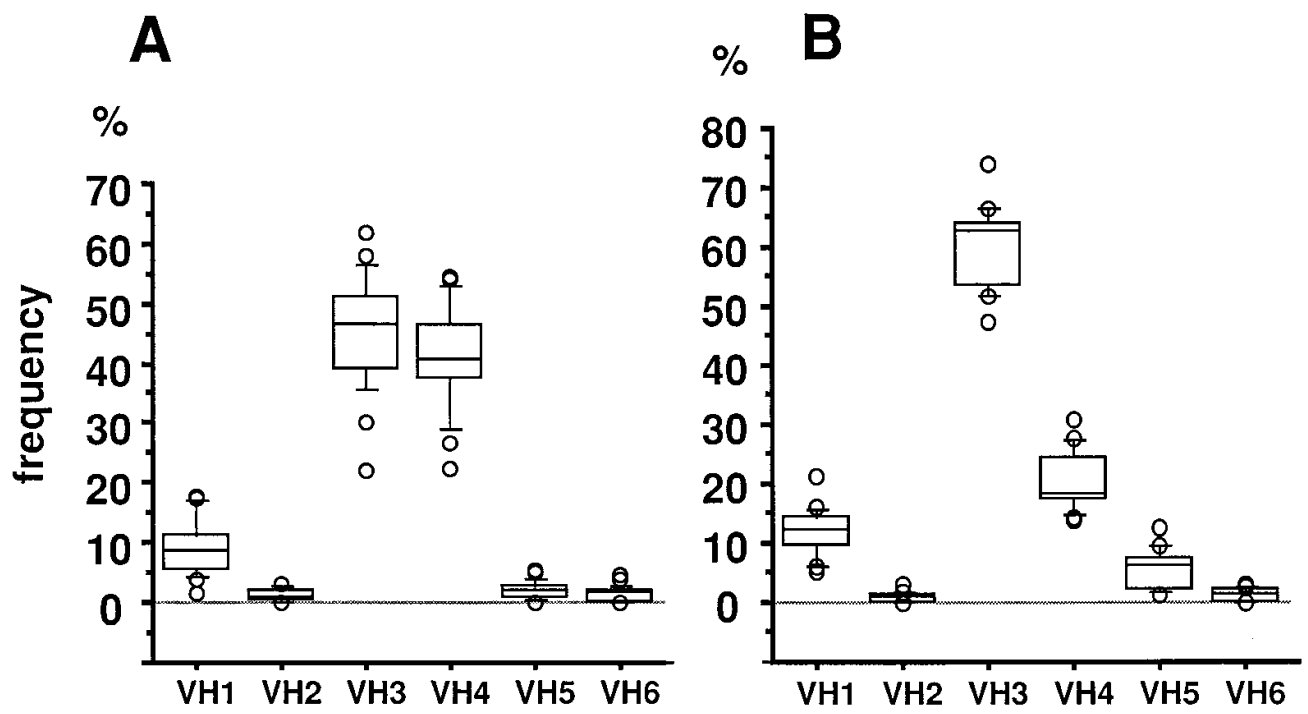

Figure 2. Expressed $\mathrm{V}_{\mathrm{H}} \mu$ and $\gamma$ gene repertoires from monozygotic twins. $(A) \mu$ repertoires of 20 twins. $(B) \gamma$ repertoires of 16 twins. The whiskers include 10 90 percentiles, and the boxes include the $25-75$ percentile values. The horizontal bars indicate median values.

12 clones had no mutations, six had one, four had two, and two had three nucleotide replacement mutations. On the other hand, among the $13 \mathrm{~V}_{\mathrm{H}} 4$ gene transcripts, 9 clones had no mutations, two had one, and two had two mutations. Those transcripts with only a single mutation hybridized well to the probes (with $70 \%$ or more efficiency), while transcripts with two or more mutations did less efficiently (with $10-40 \%$ efficiency). The leader genes of $\mathrm{V}_{\mathrm{H}} 4 \gamma$ transcripts had no more mutations than those of $\mathrm{V}_{\mathrm{H}} 3 \gamma$ transcripts.

Chronological analysis of $V_{H}$ gene repertoires. Six months after analyses of the $\mu$ and $\gamma \mathrm{V}_{\mathrm{H}}$ gene repertoires of a single healthy donor, $\mathrm{PBMC}$ were collected again for repeat $\mathrm{V}_{\mathrm{H}}$ repertoire analysis (Fig. $1 B$ ). The overall $\mathrm{V}_{\mathrm{H}}$ gene family expression patterns by both IgM and IgG B cells were remarkably stable over time.

Comparison of $\mu$ and $\gamma \mathrm{V}_{H}$ gene repertoires. To determine how genetic factors control $\mathrm{V}_{\mathrm{H}}$ gene expression, PBMC from 10 pairs of monozygotic twins were studied. The twin pairs included two healthy pairs, four pairs discordant, and four pairs concordant for RA (Table I). As is shown in Fig. $2 A$, the $\mathrm{V}_{\mathrm{H}} 3$ family genes were predominant in the $\mu$ transcripts (range $22.0-62.0 \%$, mean $45.6 \%$ ), followed by the $\mathrm{V}_{\mathrm{H}} 4$ family genes (range $22.4-54.5 \%$, mean $40.8 \%$ ). The large $\mathrm{V}_{\mathrm{H}} 1$ gene family was underrepresented (range 1.6-17.7\%, mean 8.9\%), followed by $\mathrm{V}_{\mathrm{H}} 5$ (mean $2.2 \%$ ), $\mathrm{V}_{\mathrm{H}} 2$ (mean $1.3 \%$ ), and $\mathrm{V}_{\mathrm{H}} 6$ (mean $1.2 \%$ ).

Amplification of $\gamma$ transcripts from two twin pairs did not yield sufficient PCR products for analysis. The $\mathrm{V}_{\mathrm{H}}$ gene repertoires of the other eight twin pairs are shown in Fig. $2 B$. Again, Ig $\mathrm{V}_{\mathrm{H}} 3$ family genes were expressed predominantly (range $47.3-74.1 \%$, mean $60.5 \%$ ), followed by $\mathrm{V}_{\mathrm{H}} 4$ family genes (range 14.0-30.8\%, mean $20.3 \%$ ). However, $\mathrm{V}_{\mathrm{H}} 4$ gene expression was $20.5 \%$ lower in $\gamma$ than $\mu$ transcripts. The third most frequently expressed gene family was $\mathrm{V}_{\mathrm{H}} 1$ (range 5.4$21.5 \%$, mean $11.7 \%$ ), followed by $\mathrm{V}_{\mathrm{H}} 5$ (mean $5.5 \%$ ), $\mathrm{V}_{\mathrm{H}} 6$ (mean $1.2 \%$ ), and $\mathrm{V}_{\mathrm{H}} 2$ (mean $0.8 \%$ ).

Comparison of the peripheral $B$ cell repertoires from monozygotic twins. To investigate genetic and environmental effects on the $\mathrm{V}_{\mathrm{H}}$ gene repertoires, the $\mu$ and $\gamma$ repertoires of the monozygotic twins were compared. Representative results of two pairs each from RA discordant (pairs A and B), concor- dant (pairs $\mathrm{E}$ and $\mathrm{F}$ ), and normal (pairs $\mathrm{M}$ and $\mathrm{N}$ ) twin pairs are shown in Fig. 3. The $\mu$ and $\gamma V_{H}$ repertoires were remarkably similar between monozygotic twins. The $\mathrm{V}_{\mathrm{H}}$ family gene use in $\mu$ and $\gamma$ transcripts from RA patients and control subjects were not distinguishable, despite the chronic immune stimulation and hypergammaglobulinemia characteristic of this disease.

To assess numerically the similarity of two given $V_{H}$ gene repertoires of the same isotype (either $\mu$ or $\gamma$ ), we calculated the Euclidean distance between repertoires of each combination of two individuals. The Euclidean distances of the $\mu \mathrm{V}_{\mathrm{H}}$ transcripts were significantly smaller in the monozygotic twins than in unrelated individuals $(P=0.02$, by Mann-Whitney $U$ test, Fig. 4). The data show that identical twins have more similar $\mu$ repertoires than do unrelated subjects. The distances for the $\gamma$ transcripts did not reach statistical significance because of the smaller sample size.

\section{Discussion}

Quantitative analysis of $\mu$ and $\gamma$ transcripts in peripheral blood lymphocytes from 10 pairs of adult monozygotic twins revealed that $\mathrm{V}_{\mathrm{H}}$ gene family expression was controlled by genetic factors, often could distinguish one individual from another, and remained stable despite time and disease.

The probe sequences within the leader regions of the six Ig 1-6 $\mathrm{V}_{\mathrm{H}}$ gene families were designed such that somatic hypermutation would not interfere with hybridization. PCR amplification of the Ig transcripts does not depend on $\mathrm{V}_{\mathrm{H}}$ region sequences, and potential differences of hybridization efficiencies of the probes were normalized using the $\mathrm{V}_{\mathrm{H}} 1-6$ leader DNA. Sequence analyses of cloned $\mathrm{V}_{\mathrm{H}}$ cDNAs confirmed that the leader sequence primers could hybridize to nearly all $\mathrm{Ig} \mathrm{V}_{\mathrm{H}}$ genes. Although somatic mutations in the leader regions potentially could influence the efficiency of probe hybridization, these occurred at random positions and not preferentially on specific $\mathrm{V}_{\mathrm{H}}$ family genes and, thus, did not hinder the frequency analysis. Indeed, the PCR-ELISA method, and conventional cloning and hybridization, yielded equivalent $V_{H}$ gene frequencies.

Although the $\mathrm{V}_{\mathrm{H}} 1$ and $\mathrm{V}_{\mathrm{H}} 4$ families each contain similar 

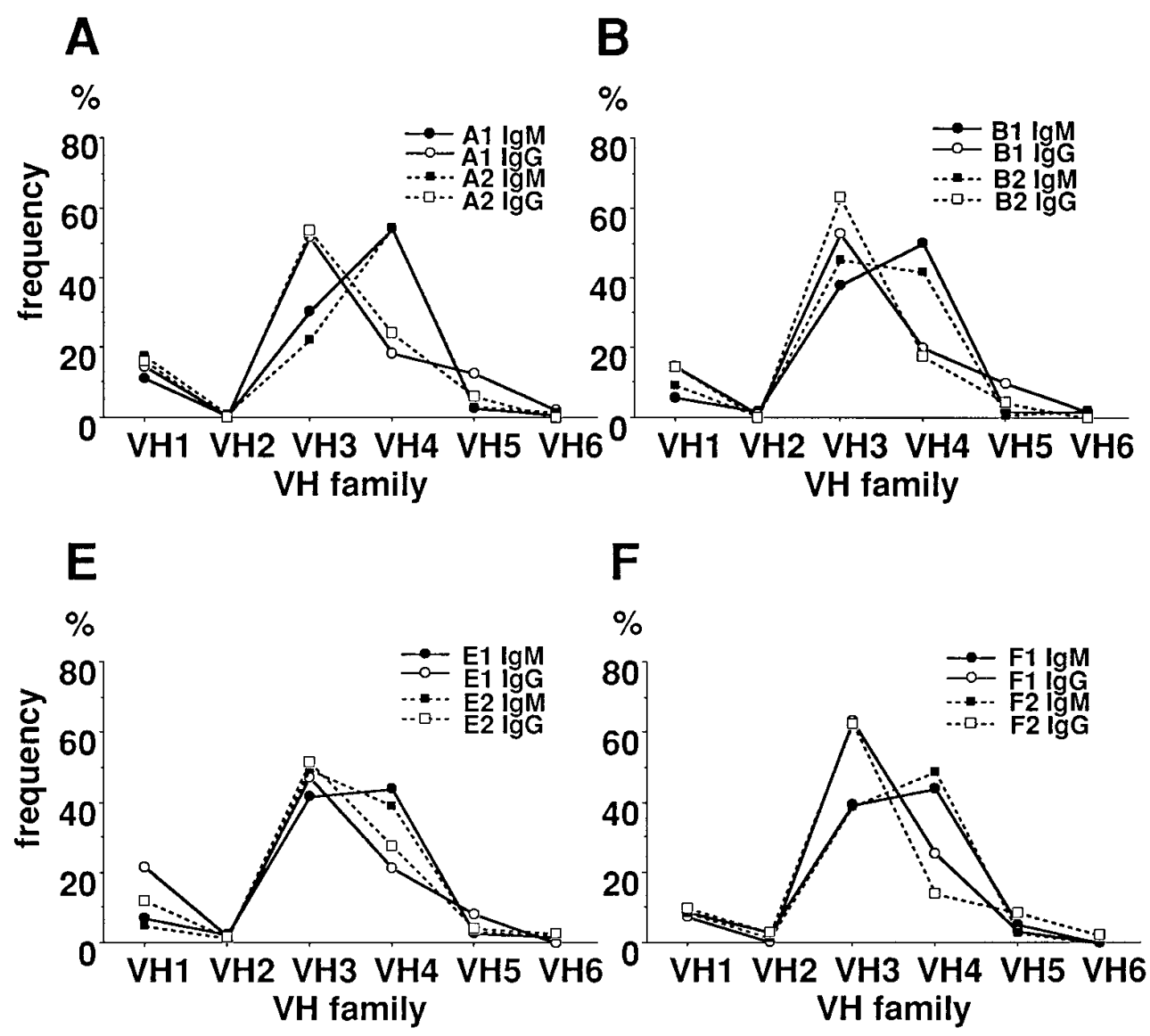

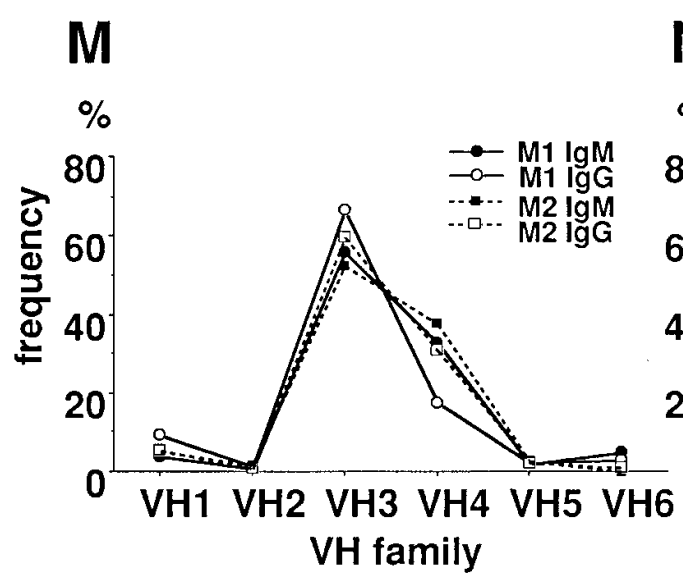

numbers of functional $\mathrm{V}_{\mathrm{H}}$ genes, $\mathrm{V}_{\mathrm{H}} 1$ genes account for fewer transcripts than $\mathrm{V}_{\mathrm{H}} 4$ in the expressed $\mathrm{V}_{\mathrm{H}}$ gene repertoire. This provides further support for the concept that functional $\mathrm{Ig} \mathrm{V}_{\mathrm{H}}$ genes are not used randomly in the normal adult B cell repertoire.

IgG B cells derive from IgM B cells by class switching after antigenic stimulation. One would expect, therefore, that the expressed IgG would depend upon environmental stimuli, while the expressed IgM would depend upon genetic and developmental factors. However, the $\mu$ and $\gamma V_{H}$ gene expression patterns were similar in all subjects. Thus, exogenous antigens do not normally skew the basic inherited pattern of $\mathrm{Ig} \mathrm{V}_{\mathrm{H}}$ gene expression by peripheral B lymphocytes. The $\mathrm{V}_{\mathrm{H}}$ family gene expression pattern does not necessarily correlate with immu- noglobulin specificity. However, $\mathrm{V}_{\mathrm{H}}$ gene usage may be related, to some extent, to the specificity of the repertoire, since it has been reported that the $\mathrm{V}_{\mathrm{H}}$ gene usage by rheumatoid factor B cells was also conserved by RA discordant monozygotic twins (25).

The fetal Ig gene repertoire is enriched in B cells with potentially self-reactive Ig receptors (2-6). These findings imply that heterogeneity of self antigens may potentially expand or delete particular naive $\mathrm{B}$ cell populations. Many different human autoantibodies use genes from the $\mathrm{V}_{\mathrm{H}} 4$ family. Positive selection by autoantigen (26) is one possible explanation for the predominance of $\mathrm{V}_{\mathrm{H}} 4$ genes in $\mu$ transcripts and to a lesser degree in $\gamma$ transcripts, which was also observed in previous studies of a single donor (27). 


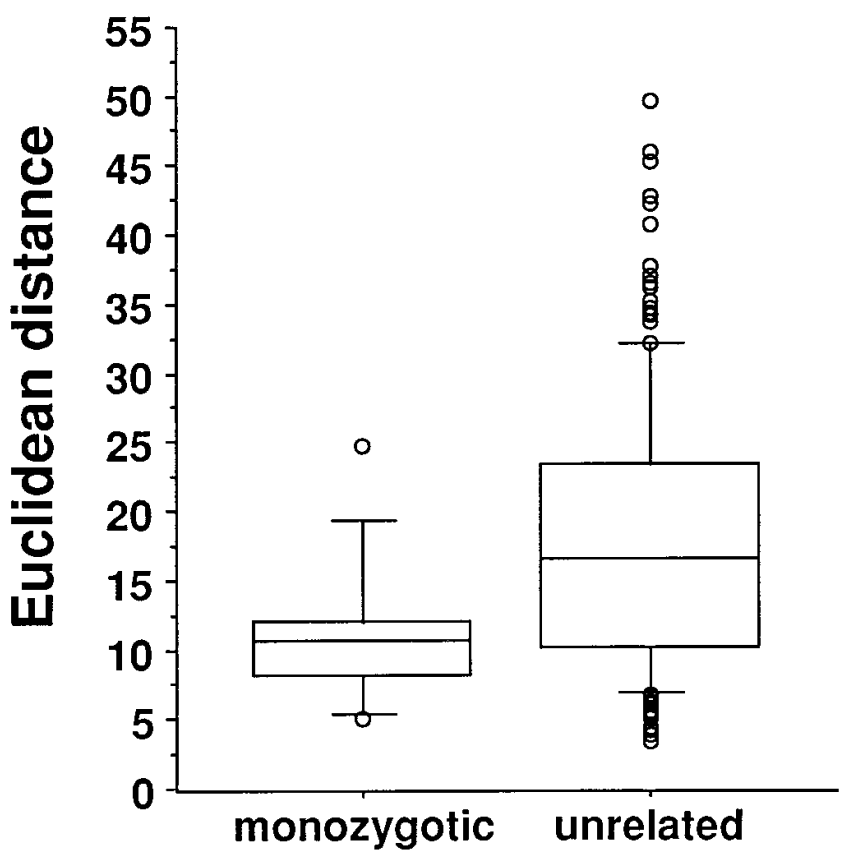

Figure 4. Comparison of $\mathrm{V}_{\mathrm{H}} \mu$ transcripts from monozygotic twins and unrelated individuals. The root of the sums of the squares of the differences (Euclidean distance) in all $\mathrm{V}_{\mathrm{H}}$ family gene frequencies between repertoires of each combination of two individuals was calculated as an indicator of discordance. The whiskers, the boxes and the horizontal bars were as described in Fig. 2.

The immunological experience of monozygotic twins should be more similar than that of unrelated individuals. However, the twins studied were all more than $39 \mathrm{yr}$ old, and lived at different locations. Moreover, RA is a systemic autoimmune disease often associated with increased Ig turnover, and with circulating autoantibodies against self IgG (rheumatoid factor). The genes encoding rheumatoid factor derive from a restricted pool $(28,29)$. We expected that the affected RA twins would have different $\mathrm{Ig} \mathrm{V}_{\mathrm{H}}$ gene repertoires from those from the unaffected, but direct analysis refuted this supposition. There were no unique biases in $\mathrm{V}_{\mathrm{H}}$ family gene usage attributable to the disease. The genetically regulated $\mathrm{V}_{\mathrm{H}}$ family gene repertoires were not grossly altered as a consequence of RA. The homogeneity of Ig V gene expression over 6 months in a normal individual also indicated that antigen exposure does not alter the inherited pattern of $\mathrm{V}_{\mathrm{H}}$ gene use.

The anchored PCR approach determines the relative frequencies of $\mathrm{V}_{\mathrm{H}}$ genes in a cDNA pool, but does not enumerate numbers of $B$ cells expressing specific $\mathrm{Ig} \mathrm{V}_{\mathrm{H}}$ family gene products. Transcription of $I g V_{H}$ genes expands severalfold after humoral immune activation by antigen, and thus should vary over time. Nonetheless, the $\mathrm{V}_{\mathrm{H}}$ gene family expression patterns of peripheral B cells were very similar in monozygotic twins and remained stable over at least 6 months.

What are the genetic factors that control $\mathrm{V}_{\mathrm{H}}$ gene family usage? Human $\mathrm{V}_{\mathrm{H}}$ genes are polymorphic both in haploid number and in structure. Three insertions of multiple $\mathrm{V}_{\mathrm{H}}$ gene segments have been reported (30-34). One insertion resulted in a gain of five functional $\mathrm{V}_{\mathrm{H}}$ genes, while the second and third led to gains of two, and one functional gene segments. The $\mathrm{V}_{\mathrm{H}}$ insertions occur in 73,50 , and $27 \%$ of normal individu- als, respectively. Allelic sequence polymorphisms in $\mathrm{V}_{\mathrm{H}}$ genes usually involve relatively few nucleotide substitutions $(35,36)$. Duplicate $\mathrm{V}_{\mathrm{H}}$ gene polymorphism also dictates expression frequency of the corresponding gene (11). Thus, differences in $\mathrm{V}_{\mathrm{H}}$ gene family expression among individuals could derive from insertion/deletion and duplicate polymorphisms, and allelic sequence polymorphisms. In mice, regulation of $\mathrm{V}_{\mathrm{H}} \mathrm{J} 558$ family gene expression in neonatal, but not adult, peripheral B cells maps to the IgH gene locus (37). Family studies are under way in our laboratory to define more precisely the genetic loci that regulate $\mathrm{V}_{\mathrm{H}}$ gene expression.

\section{Acknowledgments}

The authors thank Mihoko Suzuki for her expert technical assistance and Nancy Noon for preparing the manuscript.

This work was supported by a grant from Japanese Rheumatism Association, a grant-in-aid from the Ministry of Education and the Ministry of Health and Welfare, Japan, and National Institutes of Health grants AR-25443, AR-41897, and CA-49870.

\section{References}

1. Cook, G.P., and I.M. Tomlinson. 1995. The human immunoglobulin $\mathrm{V}_{\mathrm{H}}$ repertoire. Immunol. Today. 16:237-242

2. Schroeder, H.J., J.L. Hillson, and R.M. Perlmutter. 1987. Early restriction of the human antibody repertoire. Science (Wash. DC). 238:791-793.

3. Chen, P.P., N.J. Olsen, P.M. Yang, G.R. Soto, T. Olee, K.A. Siminovitch, and D.A. Carson. 1990. From human autoantibodies to the fetal antibody repertoire to B cell malignancy: it's a small world after all. Int. Rev. Immunol. 5: 239-251.

4. Dersimonian, H., A. Long, D. Rubinstein, B.D. Stollar, and R.S. Schwartz. 1990. $\mathrm{V}_{\mathrm{H}}$ genes of human autoantibodies. Int. Rev. Immunol. 5:253264.

5. Hillson, J.L., and R.M. Perlmutter. 1990. Autoantibodies and the fetal antibody repertoire. Int. Rev. Immunol. 5:215-229.

6. Pascual, V., J. Andris, and J.D. Capra. 1990. Heavy chain variable region gene utilization in human antibodies. Int. Rev. Immunol. 5:231-238.

7. Choi, Y., M.H. Rickert, M. Ballow, and S.J. Greenberg. 1995. Human $\mathrm{IgH}-\mathrm{V}$ gene repertoire in neonatal cord blood, adult peripheral blood, and EBV-transformed cells. Ann. N Y Acad. Sci. 764:261-264.

8. Stewart, A.K., C. Huang, B.D. Stollar, and R.S. Schwartz. 1993. High-frequency representation of a single $\mathrm{V}_{\mathrm{H}}$ gene in the expressed human $\mathrm{B}$ cell repertoire. J. Exp. Med. 177:409-418.

9. Kraj, P., D.F. Friedman, F. Stevenson, and L.E. Silberstein. 1995. Evidence for the overexpression of the $\mathrm{V}_{\mathrm{H}} 4-34\left(\mathrm{~V}_{\mathrm{H}} 4.21\right)$ Ig gene segment in the normal adult human peripheral blood B cell repertoire. J. Immunol. 154:64066420 .

10. Friedman, D.F., P. Kraj, and L.E. Silberstein. 1995. $\mathrm{V}_{\mathrm{H}} 4.21$ expression in the normal human B-cell repertoire. Ann. N Y Acad. Sci. 764:285-292.

11. Sasso, E.H., T. Johnson, and T.J. Kipps. 1996. Expression of the Immunoglobulin $\mathrm{V}_{\mathrm{H}}$ Gene 51p1 Is Proportional to Its Germline Gene Copy Number. J. Clin. Invest. 97:2074-2080.

12. Vissinga, C.S., P. Charmley, and P. Concannon. 1994. Influence of coding region polymorphism on the peripheral expression of a human TCR V beta gene. J. Immunol. 152:1222-1227.

13. Luyrink, L., C.A. Gabriel, S.D. Thompson, A.A. Grom, W.P. Maksymowych, E. Choi, and D.N. Glass. 1993. Reduced expression of a human V beta 6.1 T-cell receptor allele. Proc. Natl. Acad. Sci. USA. 90:4369-4373.

14. Charmley, P., K. Wang, L. Hood, and D.A. Nickerson. 1993. Identification and physical mapping of a polymorphic human $\mathrm{T}$ cell receptor $\mathrm{V}$ beta gene with a frequent null allele. J. Exp. Med. 177:135.

15. Kohsaka, H., P.P. Chen, A. Taniguchi, W.E.R. Ollier, and D.A. Carson. 1993. Divergent $\mathrm{T}$ cell receptor gamma repertoires in rheumatoid arthritis monozygotic twins. Arthritis Rheum. 36:213-221.

16. Akolkar, P.N., A.B. Gulwani, R. Pergolizzi, R.D. Bigler, and J. Silver. 1993. Influence of HLA genes on T cell receptor V segment frequencies and expression levels in peripheral blood lymphocytes. J. Immunol. 150:2761-2773.

17. Akolkar, P.N., A.B. Gulwani, M.A. Robinson, and J. Silver. 1995. The influence of non-HLA genes on the human T-cell receptor repertoire. Scand. J. Immunol. 42:248-256.

18. Gulwani, A.B., D.N. Posnett, C.H. Janson, J. Grunewald, H. Wigzell, P. Akolkar, P.K. Gregersen, and J. Silver. 1991. T cell receptor V-segment frequencies in peripheral blood $\mathrm{T}$ cells correlate with human leukocyte antigen type. J. Exp. Med. 174:1139-1146. 
19. Kohsaka, H., A. Taniguchi, P.P. Chen, W.E.R. Ollier, and D.A. Carson. 1993. The expressed $\mathrm{T}$ cell receptor $\mathrm{V}$ gene repertoire of rheumatoid arthritis monozygotic twins: rapid analysis by anchored polymerase chain reaction and enzyme-linked immunosorbent assay. Eur. J. Immunol. 23:1895-1901.

20. Rassenti, L.Z., H. Kohsaka, and T.J. Kipps. 1995. Analysis of immunoglobulin $\mathrm{V}_{\mathrm{H}}$ gene repertoire by an anchored PCR-ELISA. Ann. N Y Acad. Sci. 764:463-473.

21. Worthington, J., W.E.R. Ollier, M.K. Leach, I. Smith, E.M. Hay, W. Thomson, L. Pepper, D. Carthy, A. Farhan, S. Martin et al. 1994. The Arthritis and Rheumatism Council's National Repository of Family Material: pedigrees from the first 100 rheumatoid arthritis families containing affected sibling pairs. $\mathrm{Br}$. $J$. Rheumatol. 33:970-976.

22. Arnett, F.C., S.M. Edworthy, D.A. Bloch, D.J. McShane, J.F. Fries, N.S. Cooper, L.A. Healey, S.R. Kaplan, M.H. Liang, H.S. Luthra, T.A.J. Medsger, D.M. Mitchell, D.H. Neustadt, R.S. Pinals, J.G. Schaller, J.T. Sharp, R.L. Wilder, and G.G. Hunder. 1988. The American Rheumatism Association 1987 revised criteria for the classification of rheumatoid arthritis. Arthritis Rheum. 31:315-324.

23. Kohsaka, H., P.P. Chen, A. Taniguchi, W.E.R. Ollier, and D.A. Carson. 1993. Regulation of the mature human T cell receptor gamma repertoire by biased V-J gene rearrangement. J. Clin. Invest. 91:171-178.

24. Kabat, E.A., T.T. Wu, H.M. Perry, K.S. Gottesman, and C. Foeller. Sequence of Proteins of Immunological Interest. (5 ed.) U. S. Department of Health and Human Services, 1991.

25. Vencovsky, J., R.A. Mageed, W.E.R. Ollier, and R.N. Maini. 1995. Monozygotic rheumatoid arthritis twin pairs express similar levels of conserved immunoglobulin $\mathrm{V}$ gene in polyclonal rheumatoid factors irrespective of disease status. Scand. J. Immunol. 42:147-157.

26. Huang, D.F., T. Olee, Y. Masuho, Y. Matsumoto, D.A. Carson, and P.P. Chen. 1992. Sequence analyses of three immunoglobulin $\mathrm{G}$ anti-virus antibodies reveal their utilization of autoantibody-related immunoglobulin $\mathrm{Vh}$ genes, but not V lambda genes. J. Clin. Invest. 90:2197-2208.

27. Huang, C., and B.D. Stollar. 1993. A majority of Ig H chain cDNA of normal human adult blood lymphocytes resembles cDNA for fetal Ig and natural autoantibodies. J. Immunol. 151:5290-5300.

28. Deftos, M., T. Olee, D.A. Carson, and P.P. Chen. 1994. Defining the genetic origins of three rheumatoid synovium-derived IgG rheumatoid factors. $J$.
Clin. Invest. 93:2545-2553.

29. Olee, T., E.W. Lu, D.F. Huang, R. Soto-gil, M. Deftos, F. Kozin, D.A Carson, and P.P. Chen. 1992. Genetic analysis of self-associating immunoglobulin $\mathrm{G}$ rheumatoid factors from two rheumatoid synovia implicates an antigendriven response. J. Exp. Med. 175:831-842.

30. Walter, M.A., U. Surti, M.H. Hofker, and D.W. Cox. 1990. The physical organization of the human immunoglobulin heavy chain gene complex. $E M B O$ (Eur. Mol. Biol. Org.) J. 9:3303-3313.

31. Cook, G.P., I.M. Tomlinson, G. Walter, H. Riethman, N.P. Carter, L. Buluwela, G. Winter, and T.H. Rabbitts. 1994. A map of the human immunoglobulin $\mathrm{V}_{\mathrm{H}}$ locus completed by analysis of the telomeric region of chromosome 14q. Nat. Genet. 7:162-168.

32. Walter, G., I.M. Tomlinson, G.P. Cook, G. Winter, T.H. Rabbitts, and P.H. Dear. 1993. HAPPY mapping of a YAC reveals alternative haplotypes in the human immunoglobulin $\mathrm{V}_{\mathrm{H}}$ locus. Nucleic Acids Res. 21:4524-4529.

33. Willems, van Dijk, K.W., L.A. Milner, E.H. Sasso, and E.C. Milner. 1992. Chromosomal organization of the heavy chain variable region gene segments comprising the human fetal antibody repertoire. Proc. Natl. Acad. Sci. USA. 89:10430-10434.

34. van der Maarel, S., K.W. van Dijk, C.M. Alexander, E.H. Sasso, A. Bull, and E.C. Milner. 1993. Chromosomal organization of the human $\mathrm{V}_{\mathrm{H}} 4$ gene family. Location of individual gene segments. J. Immunol. 150:2858.

35. Sasso, E.H., K.W. van Dijk, A.P. Bull, and E.C. Milner. 1993. A fetally expressed immunoglobulin $\mathrm{V}_{\mathrm{H}} 1$ gene belongs to a complex set of alleles. J. Clin. Invest. 91:2358-2367.

36. Tomlinson, I.M., G. Walter, J.D. Marks, M.B. Llewelyn, and G. Winter. 1992. The repertoire of human germline $V_{H}$ sequences reveals about fifty groups of $\mathrm{V}_{\mathrm{H}}$ segments with different hypervariable loops. J. Mol. Biol. 227: 776-798.

37. Viale, A.C., A. Coutinho, and A.A. Freitas. 1992. Differential expression of $\mathrm{V}_{\mathrm{H}}$ gene families in peripheral $\mathrm{B}$ cell repertoires of newborn or adult immunoglobulin H chain congenic mice. J. Exp. Med. 175:1449-1456.

38. Jawaheer, D., W. Thompson, A.J. MacGregor, D. Cathy, J. Davidson, P.A. Dyer, and W.E.R. Ollier. 1994. "Homozygosity" for the HLA-DR shared epitope contributes the highest risk for rheumatoid arthritis concordance in identical twins. Arthritis Rheum. 37:681-686. 